\title{
The Correlation between School EFL Teachers' Effectiveness and Their Narrative Intelligence
}

\author{
Soheila Rezaei Khordkhili \\ Dept. of English Language, Science and Research, Shahr-e- Qods \\ Branch, Islamic Azad University, Tehran, Iran \\ E-mail: solirezaei20@yahoo.com
}

Behdokht Mall-Amiri (Corresponding author)

Dept. of English Language, Central Tehran Branch, Islamic Azad University, Tehran, Iran

E-mail: Beh.malamiri@iauctb.ac.ir

Received: Dec. 28, 2014 Accepted: Jan. 20, 2015 Published: February 1, 2015

doi:10.5296/jse.v5i1.6837

URL: http://dx.doi.org/10.5296/jse.v5i1.6837

\begin{abstract}
The purpose of this study was to examine the relationship between narrative intelligence of EFL (English as a foreign language) teachers and their pedagogical success at high schools. This study was carried out in high schools in Sari, Mazandaran, Iran. A population of $38 \mathrm{EFL}$ teachers took part in this project. Two main instruments were utilized in this study namely, 'the Narrative Intelligence Scale and Characteristics of Successful Teachers Questionnaire'. Teachers were also given tasks to measure their narrative intelligence. English teachers were asked to take a look at a story and then recount the story (task 1). After that, the researcher asked the teachers to describe their first day at university (task 2). In the second phase of the study, Successful Teacher Questionnaire was administered to language learners to assess their success. The data analyses revealed that there was a significant relationship between participants' Persian and English narrative intelligences and their pedagogical success. Finally, teachers' Persian and English narrative intelligences were a significant predictor of their teaching success.
\end{abstract}

Keywords: Narrative intelligence, Teachers' effectiveness, Pedagogical success 


\section{Introduction}

There seems to be a close association between successful learning and effective teaching. Based on Galluzzo (2005), teacher quality is the most salient factor in students' learning. Hence, teachers have a significant role in students' success or failure. Following this, great importance has been attached to the notion of teacher success in the field of foreign language teaching. Many research projects have been carried out to address teacher effectiveness (e.g., Elizabeth, May, \& Chee, 2008; Pishghadam \& Moafian, 2008). There are also other studies that have attempted to investigate the variables that may be related to teacher success, such as multiple intelligences, self-efficacy, or the use of NLP (Neurolinguistic Programming) techniques (e.g. Ghanizadeh \& Moafian, 2011; Pishghadam \& Moafian, 2008; Pishgadam, Shapoori, \& Shayesteh, 2011).

Elizabeth et al. (2008) introduced a model and determined the factors that affect teacher success, such as clear and in-depth delivery of the lesson and the capability of improving students' comprehension. These two factors are closely associated with Randall's (1999) concept of narrative intelligence defined as the ability to produce and comprehend narratives. Because of its nature, mostly dealing with interpersonal and intrapersonal capabilities, it appears that teachers with a high level of narrative intelligence can be more successful in teaching.

The central role played by the art of storytelling in successful leadership is confirmed by several studies (e.g. Norman, 1997) showing that stories are more effective than analytical reasoning when it comes to persuasion. Social psychology studies show that information is remembered faster and more accurate if presented as an example or story, especially a fascinating one. The power of stories is even greater as they are mythical, universal, stories that transcend cultures, that resonate deeply with human motivations and that convey complex meanings. We can experience these stories developing skills and human virtues.

It has been mentioned that teacher effectiveness is an important ingredient for successful second or foreign language education. The relationship between teacher success and various factors, such as creativity, multiple intelligences, personality traits, and emotional intelligence has been explored in previous research. The contribution of narrative intelligence to teacher effectiveness in informal language education (language institutes) has been examined (e.g. Pishghadam et al. 2011). This research project aims at investigating the contribution of narrative intelligence to language teacher effectiveness in formal language education (public and private schools). Therefore, this study tries to figure out whether there exists a significant association between language teachers' narrative intelligence and their success in language education at schools.

Consequently, investigating the possible link between narrative intelligence and teacher effectiveness can be of benefit, shedding more light on the factors influencing teacher success. To the researchers' knowledge, the association between narrative intelligence and language teachers' success has not been explored so far. Therefore, the present study aimed to investigate the relationship among EFL teachers' English and Persian narrative intelligence and their teaching effectiveness. The researchers also intended to investigate whether English 
and Persian narrative intelligences can predict EFL teachers' preference for their teaching success as a predictive variable.

\section{Review of Literature}

\subsection{Narrative Intelligence}

The concept of narrative intelligence has been vividly elucidated in the work of the French philosopher, Paul Ricoeur, who mentioned what he calls the implicit narrative intelligence that is essential to our engagement with life. Ricoeur (1987) characterizes this narrative intelligence, which he also calls phronetic intelligence, as having three key characteristics:

- A synthesis of multiple events into a singular story

- A resolution of the tension between concord and discord into a unity

- The construction of a configuration from a temporal succession.

In a similar vein, Randall (1999) wrote "without narrative intelligence it can be argued, countless processes integral to human existence are impossible, perhaps inconceivable" ( $p$. 85). Randall has discussed how narrative intelligence is involved in four salient areas: (1) the way we can express the novelty of our lives, (2) its origins in our childhood, (3) its dynamics in terms of the many familiar story conventions at play in the construction of our life stories, and (4) the alterations in the experience and expression with how we "story" our lives in later life. Randal also proposed that narrative intelligence consists of some interrelated sub-capacities that are automatic in our attempt to construct reality (Bruner, 1996). In the following, the main components of narrative intelligence are presented.

The first sub-component of narrative intelligence is empolotment. Emploting includes editing, summarizing what had happened in the past or what is currently happening, dealing with conflicts or troubles (Bruner, 1996), prioritizing that is selecting some details as more important than others, considering events of life as temporal units with beginnings, middles, and ends, and constructing situations and events "in a narrative context as they unfold" (Randall, 1999, p. 16).

Characterization, the second subcomponent of narrative intelligence, is the ability to form a picture of ourselves and others. By resorting to various cues and clues, we form a picture of how we and others are like. Randall (1995) highlighted the importance of a dynamic approach to characterization, which means continual reformulation of our perception of how others are like in light of new pieces of evidence as the narrative unfolds.

The third sub-capacity of narrative intelligence is narration. Randall (1995) contended that "it is to convey to others what is going on, has gone, or may go on, sensitive to what they understand in terms of 'logical' between events, causes, consequences, etc."(p. 17).

The fourth subcomponent of narrative intelligence is generation. Bruner (1987) considered narration as an important characteristic of storytelling and held that it provides a framework for apprehending human experience. According to Randall (1999), to generate is "to organize 
events into more or less predictable patterns or types in both telling and experiencing them" (p. 18).

Finally, thematization is being aware of recurrent patterns in the events or situations of a narrative (Birren \& Dutchman, 1991). Thematizaion includes identifying motifs or symbols and theorizing about their relevance, and understanding the theme, main idea, of a narrative (Randall, 1999).

\subsection{Teacher Success}

There are a number of definitions proposed for a successful teacher. Brown and Marks (1994) contended that effective teachers explore their own teaching experience and that of others and hence become more aware of the strong and weak points in their teaching practice. To put it differently, they carry out critical investigation of their teaching performance in the classroom (Ghanizadeh \& Moafian, 2011). Brookfield (1995) discussed several features of a successful teacher, namely applying a wide range of instructional strategies, teaching at an appropriate pace, checking students' understanding and engagement, concentrating on the topic and its educational objectives, and using humor. Anderson (2004) defined successful teacher as one who gains the intended goals, either set by themselves or by others. An implication of this definition is that successful teachers should possess the required knowledge and skills to attain the intended goals.

Elizabeth et al. (2008) suggested a model for defining teacher success. They suggested that in order to define teacher success, not only should we give attention to personal and professional characteristics, but also we should take contextual factors -such as teachers' personal context, school context, and context beyond school- into account. As far as personal qualities are concerned, they also demonstrated a number of personal qualities such as patience, sense of responsibility, caring for students, and enthusiasm. In terms of professional qualities, they pointed to factors such as clear presentation of the instructional material, the capability of improving learners' understanding, arousing motivation in students, and effective classroom management.

Pishghadam, Golparvar, Khajavi, and Iranrad (2011) found that EFL teachers' narrative intelligence is related their success. The study has been done in language institutes; however, the contribution of narrative intelligence to teachers' pedagogical effectiveness has not been examined in formal language education yet.

Language teachers' effectiveness has been considered via two strands in the literature. The first perspective deals with the knowledge, skills, and classroom behaviors of successful language teachers (Shulman, 1994), while the second view examines the personality traits of good language teachers (Gabrielatos, 2002). Moreover, the scientific enquiries on the effectiveness of language teachers have revealed that learners and teachers do not always agree in this domain. For instance, in a research project in which 200 foreign language teachers (of English, Arabic, French, and Hebrew) and 406 ninth grade language learners were surveyed and interviewed with respect to their perceptions of good language teachers, Brosh (1996) found that students and teachers agreed to a large degree on the perceived 
characteristics of good language teachers. They argued that an effective language teacher has sufficient mastery of the subject matter, which is English in this context, and has the ability to convey knowledge clearly and easily enough for students to comprehend and master that knowledge. Teachers and students also held that factors least important for good language teachers are as follows: (1) knowledge of and positive attitudes toward the native speaker culture; (2) teaching using the L2; (3) knowledge of the curriculum; (4) classroom research orientation; and (5) teacher's gender and appearance. Students and teachers in Brosh's research project differed, however, with regard to other features of good language teachers. Students attached importance to treating students fairly and being available after class, whereas teachers put emphasis on offering students successful experiences. Brosh also came to the conclusion that teacher communication style and quality of teacher/student interaction are of utmost importance in differentiating between effective and ineffective teachers.

Harris and Sass (2006) investigated the impact of teacher qualifications and in-service training on student achievement in Florida. They adopt a value-added gains model that controls for student and teacher effects. They find small effects of experience and education on teacher performance. Moreover, they observed that a teacher's college major or scholastic aptitude (SAT or ACT score) is not associated with their instructional performances.

In accordance with this line of research, Koedel and Betts (2007) adopted a value-added gains model to look at student achievement of elementary students in San Diego. Like several of the other studies, they find that teacher quality is an important predictor of student achievement, but measured teacher qualifications (experience, quality of undergraduate college, education level, and college major) have little effect on student achievement. The findings from these research projects are creatively consistent in depicting that teacher effectiveness exerts a huge impact on student achievement, but particular teacher qualifications have small effects on student achievement.

To sum up, it is clear that narrative intelligence and teachers' success and effectiveness have been attended by scholars in the field of teacher education; however, these studies did not adequately go for the relationship between narrative intelligence and teachers' effectiveness particularly in the foreign language context. Moreover, the studies reviewed were mostly concerned with language institutes, while disregarding the context of formal language education like as high school. Hence, the present study aims to explore how teachers' narrative intelligence can be in line with their success in a high school foreign language context.

\section{Research Questions}

This research project tried to answer the following questions:

RQ 1: Is there a significant relationship between EFL teachers' English and Persian narrative intelligences?

RQ 2: Is there a significant relationship between EFL teachers' English and Persian narrative intelligence and their teaching effectiveness? 
RQ 3: Does EFL teachers' English and Persian narrative intelligence significantly predict their teaching effectiveness?

\section{Methodology}

\subsection{Participants}

This study was carried out in several high schools of Al-zahra, Abozar, Bozorgmehr, Besharat, Dokhte-Iran, Ferdous, Ferdousi, Farhange-saba, Hafez, Kamal, Khaghani, Navab, Panzdahe-khordad, Payam, Sadi, Sohravardi, and kosar in Sari, Mazandaran, Iran. A population of $108 \mathrm{EFL}$ teachers took part in this project. There were 51 male (47.2\%) and 57 female (52.7\%). A sample of 38 teachers was randomly selected to participate in this study. In this sample, there were 12 male teachers (31.5\%) and 26 female teachers (68.4\%). All of the teachers participating in this study were English teachers officially employed by Iran's Ministry of Education. They were teaching at high schools in Sari. Moreover, a population of 911 students raging in 15 to 18 years of age took part in this research project. They filled out the Characteristics of Successful Teachers Questionnaire.

\subsection{Instruments}

Two main instruments were utilized in this study namely, 'Characteristics of Successful Teachers Questionnaire' and 'the Narrative Intelligence Scale', the descriptions of which are as follow.

\subsubsection{Characteristics of Successful Teachers Questionnaire (CSTQ)}

In order to measure language teachers' success in language teaching through students' evaluation, Characteristics of Successful EFL Teachers Questionnaire (Persian version), which was designed and standardized by Pishghadam and Moafian (2008) was employed. The reliability of the questionnaire has been reported as very high (90\%). It consists of 47 Likert type items followed by five alternatives ranging from strongly agree to strongly disagree measuring twelve constructs including teaching accountability, interpersonal relationships, attention to all, examination, commitment, learning boosters, creating a sense of competence, teaching boosters, physical and emotional acceptance, empathy, class attendance, and dynamism.

\subsubsection{Narrative Intelligence Scale (NIS)}

In order to measure the narrative intelligence of the participants, the NIS (Pishghadm, Baghaei, Shams, \& Shamsaee, 2011) was used. This scale consists of 35 items. With regard to the items of the narrative intelligence scale, it measures five components of narrative intelligence as emplotment, characterization, generation, narration and thematization. In terms of content validity, Pishghadam, et al. (2011) devised this scale based on the guideline proposed by Randall (1999). Statistical measure of reliability for this scale equals 0.98 .

\subsection{Procedure}

This study was conducted in two phases in several high schools in Sari, Iran. It was carried out in winter 2013 and spring 2014. First, several high schools in different regions of Sari 
were selected. Those teachers who were volunteers took part in this research project. The researchers negotiated with teachers to fix an appropriate date and time for the first part of the study i.e. the interview section. English teachers were asked to take a look at the story and then recount the story (Task1). After that, the researchers asked the teachers to tell the story of their first day at university (Task2). In both tasks, participants were required to tell the story once in their mother-tongue (Persian) and another time in English. The participants' narrative performance in both tasks was audio recorded by the researchers.

The recorded interviews were listened and scored according to the guidelines of Pishgdadam et al. (2011). A second rater, apart from the researcher, participated in the scoring process. She was an English teacher with five years of teaching experience. According to the guidelines of Narrative Intelligence Scale, two raters scored to each item separately and then summed them. Each item received a score of 1 to 5 producing a score range of 35 to 175 .

In the second phase of the study, Successful Teacher Questionnaire (Persian version) was administered to the language learners to assess their English teachers' success. The researchers were present in the administration session and explained to the students what they were supposed to do. It goes without saying that the questionnaire has clear directions for participants illustrating what they are supposed to do.

\subsection{Data Analysis}

In order to answer the research questions, Pearson correlation coefficient and standard regression were calculated. Moreover, inter-rater reliability of the two raters' scores was also calculated through Pearson correlation formula.

\section{Results}

The present study follows three purposes. First, it explores the relationship between the teachers' English and Persian narrative intelligence. Second, it aims to figure out whether the teachers' English and Persian narrative intelligence is in relation with their teaching effectiveness. Last but not the least; it intends to probe if the teachers' narrative intelligence can be as a predictor of their teaching success and effectiveness. To answer these questions, the following statistical information is presented.

\subsection{Descriptive Statistics of English Narrative Scores}

Firstly, the researcher had to make sure that there was consistency between the two raters' narrative scores. Therefore, the correlation between their scores was calculated. The normality condition had to be checked as well. The following table shows the skewness ratios of the English narrative sets of scores given by both raters. 
Table 1. Descriptive Statistics of English Narrative Scores by the Two Raters

\begin{tabular}{|l|r|r|r|r|r|r|}
\hline & \multicolumn{1}{|c|}{$\mathrm{N}$} & \multicolumn{1}{c|}{ Mean } & Std. Deviation & \multicolumn{2}{|c|}{ Skewness } & \multicolumn{1}{c|}{$\begin{array}{c}\text { Skewness } \\
\text { Ratios }\end{array}$} \\
\cline { 2 - 7 } & Statistic & Statistic & Statistic & Statistic & Std. Error & \\
\hline English, R1 & 38 & 111.8947 & 20.69964 & .470 & .383 & 1.23 \\
English R2 & 38 & 105.7368 & 25.39598 & .243 & .383 & .63 \\
Valid N (listwise) & 38 & & & & & \\
\hline
\end{tabular}

As both ratios are within the normality range of \pm 1.96 , as depicted in Table 1 , it is concluded that both sets of scores were normally distributed; hence, the normality assumption for Pearson correlation is met. Figure 1 shows the linearity of the correlation between the two sets of scores visually.

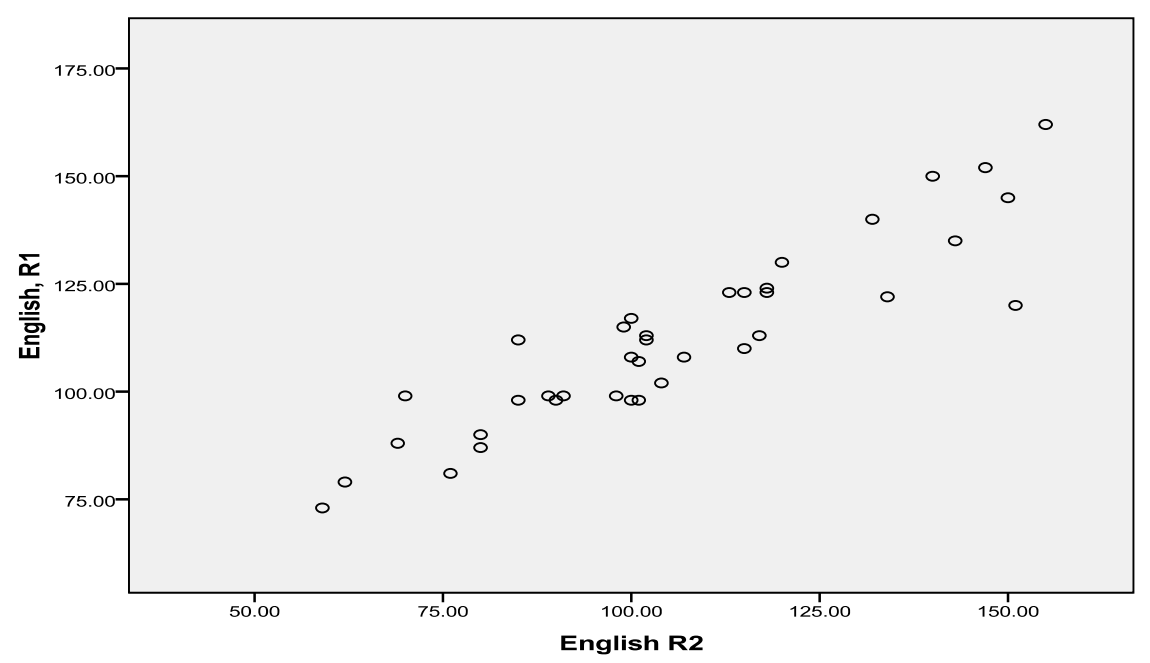

Figure 1. Scatter Plot of the Correlation between the Two Rater's English Narrative Scores

As Figure 1 shows, all the dots cluster around a straight line stretching from the bottom left to the top right, hence linearity of the relationship. So, the linearity condition for Pearson correlation is also met.

Table 2 shows the result of the Pearson correlation calculation between the scores given by the two raters to the English narrations. 
Table 2. Pearson Correlation of English Narrative Scores by the Two Raters

\begin{tabular}{|ll|r|r|}
\hline & & English, R1 & English R2 \\
\hline English, R1 & Pearson Correlation & 1 & $.912^{* *}$ \\
& Sig. (2-tailed) & & .000 \\
& $\mathrm{~N}$ & 38 & 38 \\
\hline English R2 & Pearson Correlation & $.912^{* *}$ & 1 \\
& Sig. (2-tailed) & .000 & \\
& $\mathrm{~N}$ & 38 & 38 \\
\hline
\end{tabular}

**. Correlation is significant at the 0.01 level (2-tailed).

As Table 2 depicts, the correlation between the two sets of English narrative scores given by the two raters was significant $(\mathrm{r}=.912, \mathrm{p}=.000<.05)$. Therefore, the average scores could be safely used for further calculations. The same procedure was followed for Persian narrative intelligence.

\subsection{Descriptive Statistics of Persian Narrative Scores}

Table 3 shows the descriptive statistics of Persian narrative scores of the tow raters.

Table 3. Descriptive Statistics of Persian Narrative Scores by the Two Raters

\begin{tabular}{|l|r|r|r|r|r|r|}
\hline & \multicolumn{1}{|c|}{$\mathrm{N}$} & Mean & Std. Deviation & \multicolumn{2}{|c|}{ Skewness } & $\begin{array}{c}\text { Skewness } \\
\text { Ratios }\end{array}$ \\
\cline { 2 - 7 } & Statistic & Statistic & Statistic & Statistic & Std. Error & \\
\hline Persian R1 & 38 & 123.6842 & 22.30635 & -.134 & .383 & -.35 \\
Persian R2 & 38 & 121.6842 & 23.10739 & .166 & .383 & .43 \\
Valid N (listwise) & 38 & & & & & \\
\hline
\end{tabular}

As indicated in Table 3, the skewness ratios are less than 1.96, meaning that the two sets of scores are normally distributed, hence the condition for Pearson correlation is met. Figure 2 shows the correlation between the two raters of Persian narration visually as the following. 


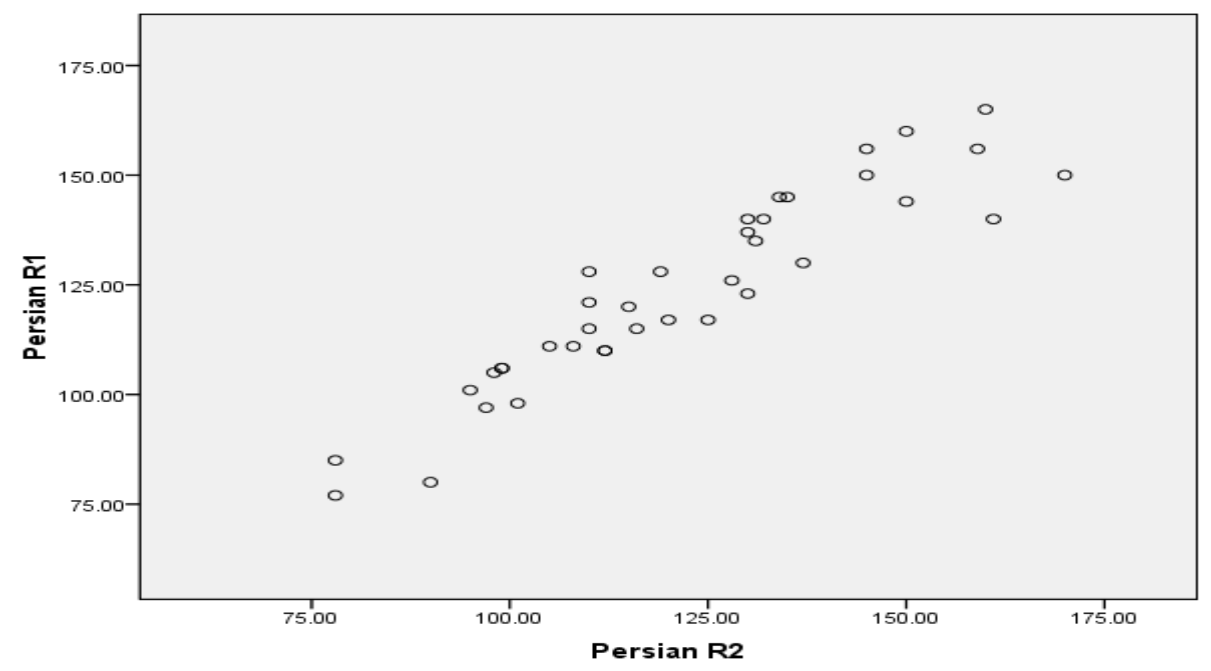

Figure 2. Scatter plot of the Correlation between the Two Rater's Persian Narrative Scores

As depicted in Figure 2, the dots tightly form a straight line which ensured linearity of the distribution as a condition for Pearson correlation. Table 4 shows the result of the Pearson correlation calculation.

Table 4. Pearson Correlation of Persian Narrative Scores by the Two Raters

\begin{tabular}{|rl|r|r|}
\hline & & Persian R1 & Persian R2 \\
\hline Persian R1 & Pearson Correlation & 1 & $.932^{* *}$ \\
& Sig. (2-tailed) & & .000 \\
& N & 38 & 38 \\
\hline Persian R2 & Pearson Correlation & $.932^{* *}$ & 1 \\
& Sig. (2-tailed) & .000 & \\
& N & 38 & 38 \\
\hline
\end{tabular}

**. Correlation is significant at the 0.01 level (2-tailed).

As exhibited in Table 4, the correlation between the Persian narrative scores given by the two raters was significant $(\mathrm{r}=.932, \mathrm{p}=.000<.05)$. As such, their mean scores could safely be used for further calculations.

\subsection{Analysis of First Research Question}

The first research question underlying the current study was "is there a significant relationship between EFL teachers' English and Persian narrative intelligences?" To answer the first research question, Pearson correlation was employed. To adopt this measure, descriptive statistics were employed which is shown in Table 5. 
Table 5. Descriptive Statistics of English and Persian Narrative Scores

\begin{tabular}{|l|r|r|r|r|r|r|}
\hline & \multicolumn{1}{|c|}{$\mathrm{N}$} & \multicolumn{1}{c|}{ Mean } & Std. Deviation & \multicolumn{2}{|c|}{ Skewness } & $\begin{array}{c}\text { Skewness } \\
\text { ratios }\end{array}$ \\
\cline { 2 - 7 } & Statistic & Statistic & Statistic & Statistic & Std. Error & \\
\hline English Narrative & 38 & 108.9079 & 22.42159 & .326 & .383 & .85 \\
Persian Narrative & 38 & 122.6711 & 22.30509 & -.039 & .383 & -.10 \\
Valid N (listwise) & 38 & & & & & \\
\hline
\end{tabular}

As indicated in Table 5, the ratios are both within the normality range of \pm 1.96 . So, the normality condition is met. Therefore, the sort of correlation between English and Persian narrative intelligence can be calculated as the following table indicates.

Table 6. Correlation between English and Persian Narrative Scores

\begin{tabular}{|cc|c|c|}
\hline & & $\begin{array}{c}\text { English } \\
\text { Narrative }\end{array}$ & $\begin{array}{c}\text { Persian } \\
\text { Narrative }\end{array}$ \\
\hline English Narrative & $\begin{array}{c}\text { Pearson Correlation } \\
\text { Sig. (2-tailed) }\end{array}$ & 1 & $.957^{* *}$ \\
& $\mathrm{~N}$ & 38 & .000 \\
& Pearson Correlation & $.957^{* *}$ & 38 \\
\hline & Sig. (2-tailed) & .000 & 1 \\
$\mathrm{~N}$ & 38 & 38 \\
\hline
\end{tabular}

As Table 6 shows, the correlation between the teachers' English and Persian narrative scores turned out to be significant $(\mathrm{r}=.95, \mathrm{p}=.000<.05)$. This reveals that both English and Persian narration of the teachers were in line together.

\subsection{Analysis of Second Research Question}

The second question that the present study aimed to answer was "is there a significant relationship between EFL teachers' English and Persian narrative intelligence and their teaching effectiveness?" Here, it is better to go for the relationship between English narrative intelligence and teaching effectiveness in one hand, and analyze the relationship between Persian narrative intelligence and teaching effectiveness separately. The following table shows relationship between English narrative intelligence and teaching effectiveness. 


\section{Macrothink

Table 7. Correlation between Teaching Effectiveness and English Narrative Intelligence

\begin{tabular}{|ll|r|r|}
\hline & & \multicolumn{1}{|c|}{$\begin{array}{c}\text { English } \\
\text { Narrative }\end{array}$} \\
\hline Teaching & Pearson Correlation & 1 & $.372^{*}$ \\
effectiveness & Sig. (2-tailed) & & .023 \\
& $\mathrm{~N}$ & 37 & 37 \\
\hline English Narrative & Pearson Correlation & $.372^{*}$ & 1 \\
& Sig. (2-tailed) & .023 & 38 \\
& $\mathrm{~N}$ & 37 & \\
\end{tabular}

*. Correlation is significant at the 0.05 level (2-tailed).

As shown in Table 7, the correlation between teachers success and effectiveness and English narrative was significant $(\mathrm{r}=.37, \mathrm{p}=.023<.05)$. However, the correlation is not that high. It seems that the learners' assessment of a successful teacher was to some extent related to the teacher's narrative intelligence in English. The next table indicates the correlation between Persian narrative intelligence and teaching effectiveness.

Table 8. Correlation between Teaching Effectiveness and Persian Narrative Intelligence

\begin{tabular}{|ll|r|r|}
\hline & & \multicolumn{1}{|c|}{$\begin{array}{c}\text { Persian } \\
\text { Narrative }\end{array}$} \\
\hline Teaching & Pearson Correlation & 1 & $.363^{*}$ \\
effectiveness & Sig. (2-tailed) & & .027 \\
& $\mathrm{~N}$ & 37 & 37 \\
\hline Persian Narrative & Pearson Correlation & $.363^{*}$ & 1 \\
& Sig. (2-tailed) & .027 & \\
& $\mathrm{~N}$ & 37 & 38 \\
\hline
\end{tabular}

As Table 8 shows, the correlation between teachers' success and their Persian narrative intelligence also turned out to be significant $(\mathrm{r}=.36, \mathrm{p}=.027<.05)$. The magnitude of this correlation, however, turned out to be low (.36).

With respect to the second research question, it can be concluded that there was a significant relationship between teachers' English and Persian narrative intelligence and their teaching effectiveness.

\subsection{Analyzing the Third Research Question}

The third research question of the study aimed at finding out whether EFL teachers' English and Persian narrative intelligence significantly can predict their teaching effectiveness. To estimate the predictability of the two independent variables (Persian and English narrative 


\section{Macrothink}

Journal of Studies in Education

ISSN 2162-6952

2015, Vol. 5, No. 1

intelligences) about the dependent variable (teaching effectiveness), standard regression was needed. To conduct regression analysis, first, the predictability of English narrative intelligence about teaching effectiveness is provided, and the predictability of Persian narrative intelligence concerning teaching effectiveness is subsequently presented in the following tables. Table 9 shows teachers' English narrative intelligence prediction of their teaching effectiveness.

Table 9. Teachers' English Narrative Intelligence Prediction of Teaching Effectiveness

\begin{tabular}{|c|c|c|c|c|c|c|c|c|c|c|c|c|}
\hline \multirow[b]{2}{*}{ Model } & \multicolumn{2}{|c|}{$\begin{array}{c}\text { Unstandardized } \\
\text { Coefficients }\end{array}$} & \multirow{2}{*}{$\begin{array}{c}\begin{array}{c}\text { Standardized } \\
\text { Coefficients }\end{array} \\
\text { Beta }\end{array}$} & \multirow[b]{2}{*}{$\mathrm{t}$} & \multirow[b]{2}{*}{ Sig. } & \multicolumn{2}{|c|}{$\begin{array}{c}95.0 \% \\
\text { Confidence } \\
\text { Interval for B }\end{array}$} & \multicolumn{3}{|c|}{ Correlations } & \multicolumn{2}{|c|}{$\begin{array}{c}\text { Collinearity } \\
\text { Statistics }\end{array}$} \\
\hline & B & $\begin{array}{l}\text { Std. } \\
\text { Error }\end{array}$ & & & & $\begin{array}{l}\text { Lower } \\
\text { Bound }\end{array}$ & $\begin{array}{l}\text { Upper } \\
\text { Bound }\end{array}$ & Zero-order & Partial & Part & Tolerance & VIF \\
\hline $\begin{array}{c}1 \text { (Constant) } \\
\text { English } \\
\text { Narrative }\end{array}$ & $\begin{array}{r}134.728 \\
.425\end{array}$ & $\begin{array}{r}19.879 \\
.179\end{array}$ & .372 & $\begin{array}{l}6.778 \\
2.374\end{array}$ & $\begin{array}{l}.000 \\
.023\end{array}$ & $\begin{array}{r}94.372 \\
.061\end{array}$ & $\begin{array}{r}175.084 \\
.788\end{array}$ & .372 & .372 & .372 & 1.000 & 1.000 \\
\hline
\end{tabular}

a. Dependent Variable: Teacher success

As to the Table, the predictability of the independent variable about the dependent one turned out to be significant $(\mathrm{B}=.372, \mathrm{p}=.023<.05)$. Therefore, the teachers' English narrative intelligence could also significantly predict their teaching effectiveness and success. Table 10 depicts the predictability of Persian narrative intelligence about teaching effectiveness.

Table 10. Teachers' Persian Narrative Intelligence Prediction of Teaching Effectiveness

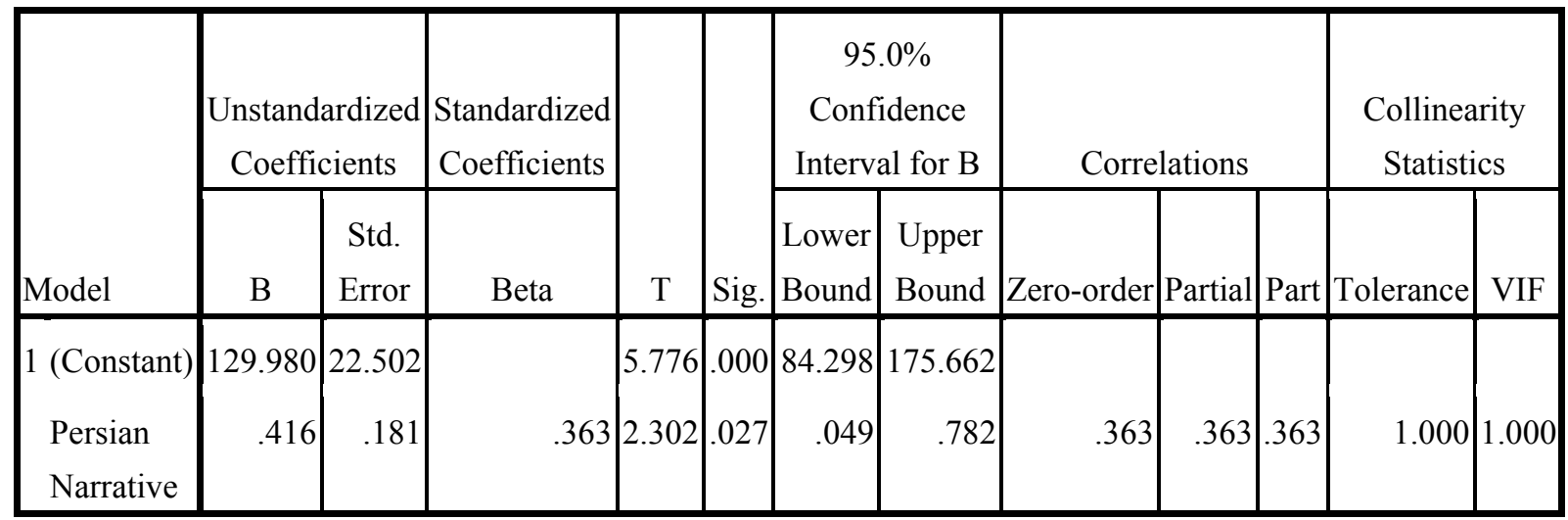

a. Dependent Variable: Teacher success

As Table 10 depicts, the Beta value turned out to be significant $(B=.36, p=.027<.05)$. Therefore, it is concluded that the teacher's Persian narrative intelligence could significantly predict their success.

As the two tables above show, both independent variables i.e. English and Persian Narrative intelligences could significantly predict the teachers' teaching effectiveness, and there is no major difference in the predictability of Persian and English narrative intelligences about 
their teaching success ( Persian: $\mathrm{B}=.363$, English: $\mathrm{B}=.372$ ), where both predictabilities turned out to be significant.

\section{Discussion}

The answer to the first research question showed that EFL teachers' English and Persian narrative abilities are significantly related. In other words, those teachers who enjoy high narrative ability in their mother tongue are likely to have high narrative intelligence in their foreign language. It should be noted that according to Randall (1999), narrative intelligence is a language-independent construct.

The second research question revealed that there existed significant relationships between EFL teachers' English and Persian narrative intelligence and their teaching effectiveness. To put it differently, EFL teachers' narrative intelligence - either in their mother tongue or a foreign language - played a positive role in their pedagogical success.

In order to account for this finding, one should pay attention to the abilities that the components of narrative intelligence bestow upon teachers. The ability to emplot enables qualified EFL teachers to choose the most significant and relevant instructional items. Another manifestation of emplotment is to connect events, i.e. arranging what is stated in a chronological order and also making it inter-related (Randall, 1999). Emplotment can also be manifested in the ability to produce different versions of a particular concept or event (Randall, 1999). Effective and successful teachers can also make use of various instructional techniques and provide instructional techniques in different formats so that learners with various learning styles have the opportunity to understand and learn the lesson (Elizabeth et al., 2008; Pishghadam \& Moafian, 2008). Similarly, in order to increase teacher effectiveness, Anderson (2004) recommended multiple modes of presentation because it enhances student learning. Emplotment can probably equip teachers to present particular instructional points in different versions so that learners with different cognitive styles can master it.

Another component is characterization. In order to gain pedagogical success, language teachers should characterize their learners. In other words, they should become aware of their students' thoughts and feelings. The literature on effective EFL teachers indicates that they should try to understand their learners as completely as possible in order to tailor instruction to their needs. Familiarity with language learners and showing empathy with them will also enable EFL teachers to establish rapport with them (Pishghadam \& Moafian, 2008).

The third research question revealed that Iranian EFL learners' English and Persian narrative intelligences are significant predictors of their pedagogical effectiveness. This finding provides further support for the close link between narrative intelligence and teacher success. Therefore, the same justifications provided for the association between narrative intelligence and teacher success can be propounded here.

Thematization deals with finding the major points of a narrative (Randall, 1999). It goes without saying that effective instructors can pinpoint and highlight the salient points of a lesson, concentrating more on them. For example, language teachers are required to indicate the major grammatical and lexical points for learners, making them more cognizant and 
conscious of them. Moreover, it was found that there was a significant relationship between teacher success and narration. Narration means putting the events and characters in the right order from the beginning to the end (Randall, 1999). Of course, effective instructors try to deliver the materials in order. They know how to connect different sections of a lesson by employing appropriate vocabularies and structures.

\section{Conclusion}

This study, over all, indicated that there existed a significant relationship between EFL teachers' narrative intelligence and their pedagogical success. Moreover, the findings of this research suggested that the teachers' narrative intelligence can be a good predictor of their teaching success.

The present research suggested that the importance of narrative intelligence and the role it may have in teacher effectiveness should be highlighted for language educators so that they can illustrate this importance for in-service EFL teachers and student-teachers. In addition, the discussions on narrative intelligence should be included in the theoretical section in the curricula of Teacher Training Courses (TTC). Finally, policy makers and teacher educators should make an attempt to folder student-teachers' narrative intelligence by providing them with appropriate narrative-centered learning environments.

\section{References}

Anderson, L.W. (2004). Increasing teacher effectiveness. Paris: UNESCO, IIEP.

Birren, J. E., \& Dutchman, D. E. (1991). Guiding autobiography groups for older adults: Exploring the fabric of life. Baltimore, MD: The John Hopkins University Press.

Brookfield, S. (1995). Becoming a critically reflective teacher. San Francisco: Jossey Bass.

Brosh, H. (1996). Perceived characteristics of an effective language teacher. Foreign Language Annals, 29(2), 125-38. http://dx.doi.org/10.1111/j.1944-9720.1996.tb02322.x

Brown, T., \& Marks, J. (1994). Inside teaching. New York: Macmillan.

Bruner, J. (1987). Life as narrative. Social Research, 54, 11-32.

Bruner, J. (1996). The culture of education. Cambridge, MA: Harvard University Press.

Elizabeth, C. L., May, C.M., \& Chee, P. K. (2008). Building a model to define the concept of teacher success in Hong Kong. Teaching and Teacher Education, 24, 623-634. http://dx.doi.org/10.1016/j.tate.2007.09.007

Gabrielatos, C. (2002). The shape of the language teacher. Paper presented at the 36th Annual International Association of Teachers of English as a Foreign Language Conference. York, England.

Galluzzo, G. R. (2005). Performance assessment and renewing teacher education. The possibilities of the NBPTS standards. The Clearing House: A Journal of Educational Strategies, Issues and Ideas, 78(4), 142-145. http://dx.doi.org/10.3200/TCHS.78.4.142-145 


\section{Macrothink}

Journal of Studies in Education

ISSN 2162-6952

2015, Vol. 5, No. 1

Ghanizadeh, A., \& Moafian, F. (2011). The relationship between Iranian EFL teachers' Sense of self-efficacy and their pedagogical success in language institutes. Asian EFL Journal, 17, 249-272.

Harris, D., \& Sass, T. (2006). The Effects of teacher training on teacher value-added. Working Papers Florida State University, 3(1), 1-44.

Koedel, C., \& Betts, J. (2007). Re-Examining the role of teacher quality in the educational production function. Working Paper, University of California, San Diego.

Norman, B. (1997). Language and identity. TESOL Quarterly, 31(3), 44-62.

Pishghadam, R., Baghaei, P., Shams, M. A., \& Shamsaee, S. (2011). Construction and validation of a narrative intelligence scale with the Rasch rating scale model. TheInternational Journal of Educational and Psychological Assessment, 8(1), 75-90.

Pishghadam, R., Golparvar, S. E., Khajavi, G. H., and Iranrad, E. (2011). Narrative intelligence and pedagogical success: A case of Iranian EFL teachers. Brazilian English Language Teaching Journal, 2(2), 178-189.

Pishghadam, R., \& Moafian, F. (2008). The role of Iranian EFL Teachers' multiple Intelligences in their success in language teaching at High schools. Pazhuhesh-eZabanha-ye- Khareji, 42, 5-22.

Pishghdam, R., Shapoori, M., \& Shayesteh, S. (2011). NLP and its relationship with teacher success, gender, teaching experience, and degree: A comparative study. World Journal of English Language, 1, 2-8.

Randall, W. L. (1995). The stories we are: An essay on self-creation. Toronto: University of Toronto Press.

Randall, W. L. (1999). Narrative intelligence and the novelty of our lives. Journal of Aging Studies, 13, 11-28. http://dx.doi.org/10.1016/S0890-4065(99)80003-6s

Ricoeur, P. (1987) Life: A story in search of a narrator. In M. C. Doeser and J.N. Kraay (Eds.), Facts and values: Philosophical reflections from western and non-western perspectives (pp. 121-132). Dordrecht: Martinus Nijhoff.

Shulman, L. S. (1994). Those who understand: Knowledge and growth in teaching. In B. Moon \& A. Sheldon Mayes (Eds.), Teaching and learning in the secondary school (pp. 4-14). New York: Routledge. 